\title{
Peran Ganda Istri Komunitas Petani
}

\author{
Suardi \\ Universitas Muhammadiyah Makassar \\ suardi@unismuh.ac.id
}

\author{
Syarifuddin \\ Universitas Muhammadiyah Makassar \\ syarifuddin@unismuh.ac.id
}

\begin{abstract}
ABSTRAK
Setiap anggota masyarakat dalam suatu keluarga memiliki status dan peranan yang berbeda dalam keluarga yang bisa dikostruksi oleh sosial budaya, biologi dan agama, namun peran laki-laki sekarang banyak dilakukan oleh perempuan. Tujuan penelitian ini adalah untuk mengetahui : (i) peran ganda istri komunitas petani (ii) implikasi sosial peran ganda intri komunitas petani. Penelitian ini menggunakan pendekatan deskriptif kualitatif dan teknik purposive sampling.Teknik penelitian observasi, wawancara dan dokumentasi.Kategori yang digunakan yaitu informan kunci dan informan umum, melalui teknik keabsahan data triangulasi sumber, teknik dan waktu. Hasil penelitian perang ganda istri komunitas petani dalam lingkup domestik yaitu memasak, dan membersihkan rumah dan memdidik anak sedangkan dalam lingkup publik membantu pekerjaan suami di sawah dikebun dan membantu memelihara ternak, dan dampak negatif yaitu perasaan bersalah, stres, kelelahan, ketidakberdayaan, kecemasan, kesedihan dan kemarahan, sedangkan dampak positifnya yaitu meningkatkan perilaku beragama, mendukung ekonomi keluarga, relasi yang sehat dan positif dengan keluarga dan pemenuhan hubungan sosial secara harmonis (equilibrium)
\end{abstract}

Kata Kunci : Beban Ganda, Perempuan, Petani.

\section{PENDAHULUAN}

Keluarga merupakan unit kesatuan sosial terkecil yang mempunyai peranan yang sangat penting dalam membina anggota-anggotanya.Setiap anggota dari suatu keluarga dituntut untuk mampu dan terampil dalam menanamkan peranan sesuai dengan kedudukannya termasuk peranan suami dan istri yang berdasarkan konstruksi sosial budaya, biologi dan agama.Namun kenyataannya sekarang banyak dijumpai para perempuan ikut terjun dalam pekerjaan suami guna untuk membantu ekonomi keluarganya yang dikenal dengan istilah gender.Gender adalah suatu konsep sosial budaya, yang digunakan untuk menggambarkan peran, fungsi, dan perilaku laki-laki serta perempuan, dalam semua kesempatan perempuan dapat berperan aktif secara maksimal sebagai mitra sejajar laki-laki dalam masyarakat dan keluarga dengan sikap saling menghargai, saling menghormati, saling mengisi dan membantu.Peran aktif perempuan dalam perekonomian keluarga untuk memberikan tambahan pendapatan untuk memenuhi 
kekurangan ekonomi rumah tangganya, hal ini dijumpai pada istri atau ibu rumah tangga di Masyarakat Bungung Katammung Kabupaten Bantaeng.

\section{LANDASAN TEORI}

Soerjono Soekanto (2012) Mengemukakan masyarakat adalah orang-orang yang hidup bersama, yang menghasilkan kebudayaan sedangkan Mansur Fakihdalam Ferawati (2013) Masyarakat adalah sebuah sistem yang terdiri atas bagian-bagian yang saling berkaitan dan masing-masing bagian secara terus menerus mencari keseimbangan (equilibrium) dan harmoni.Jadi dapat disimpulkan bahwa masyarakat adalah kesatuan hidup manusia yang berinteraksi sesuai dengan system adat-istiadat tertentu yang sifatnya berkesinambungan, dalam masyarakat terdapat suatu kelompok sosial atau suatu komunitas. Kertajaya Hermawan dalam Rahmawati (2012) menjelaskan komunitas adalah sekelompok orang yang saling peduli satu sama lain lebih dari yang seharusnya, dimana dalam sebuah komunitas terjadi relasi pribadi yang erat antar para anggota komunitas tersebut karena adanya kesamaan interest atau values.Sedangkan menurut Soenarno dalam Rahmawati (2012) Komunitas adalah sebuah identifikasi dan interaksi sosial yang dibangun dengan berbagai dimensi kebutuhan fungsional.Jadi, dapat disimpulkan bahwa komunitas adalah suatu kumpulan orang-orang tertentu pada suatu wilayah tertentu dan waktu tertentu yang membentuk kelompok-kelompok sosial, sekelompok orang yang saling peduli satu sama lain lebih dari yang seharusnya, dimana dalam sebuah komunitas yang kemudian menghasikan kebudayaan dan peraturanperaturan yang dijadikan dasar bersama, serta dapat bertindak secara kolektif dalam mencapai tujuan yang sama. Dalam suatu komunitas akan terdapat unsur-unsur yang mendukung terbentuknya komunitas. Unsur-unsur komunitas adalah sebagai berikut:

1) Manusia (people). Manusia atau setiap individu akan membentuk sekelompok individu yang sejenis (manusia) yang akan membentuk komunitas dan menghasilkan kebudayaan.

2) Kelompok Sosials. Kelompok sosial atau social group adalah himpunan atau kesatuan manusia yang hidup bersama disebabkan oleh adanya hubungan antar mereka yang menyangkut hubungan timbal balik yang saling mempengaruhi dan adanya kesadaran untuk saling menolong. Sekelompok orang tersebut mempunyai kesadaran bersama akan keanggotaan. (R.M MacIver dan Charles H, 1961:213)

3) Kebudayaan (Adat-istiadat, norma/nilai budaya). Kata "kebudayaan" berasal dari (bahasa sansekerta) buddhayah yang merupakan bentuk jamak dari "buddhi" yang 
berarti budi atau akal. Kebudayaan diartikan sebagai hal-hal yang bersangkutan dengan budi atau akal.

4) Territorial (territory). Letak wilayah atau letak geografis mendorong sekelompok orang untuk membentuk sebuah kelompok sosial atau komunitas yang menjadi cirri khas dari kondisi geografis tempat tinggal mereka. Contoh, komunitas tani di daerah dataran rendah, kelompok penanam the di dataran tingg, komunitas peternak sapi di padang rumput.

5) Status dan peran. Peranan dari komunitas adalah untuk membentuk suatu kelompok yang sama-sama mempunyai tujuan atau kesamaan dalam bidang tertentu untuk mencapai tujuan itu bersama-sama.

Salah satu komunitas yang ada dalam masyarakat adalah komunitas Perempuan bekerja, terutama perempuan yang sudah bekerja yang akan memberikan tambahan pendapatan untuk menutupi kekurangan ekonominya, Kehidupan sehari-hari perempuan berada dalam suatu konteks beban ganda. Beban untuk memberikan pengasuhan yang tak dibayar dalam pelayanan-pelayanan dalam pekerjaan rumah tangga, serta beban untuk memberikan kelangsungan hidup perekonomian melalui kerja upahan, memberikan norma bagi perempuan yang rasional dari keduanya, dua hal itu merupakan aktivitas yang tak terpisahkan bagi wanita. (Ollenburger:2002).

Keluarga merupakan lembaga sosial yang terkecil dari masyarakat yang terdiri dari sekelompok manusia yang hidup bersama dengan adanya ikatan perkawinan, hubungan darah dan adopsi. Keluarga dan berkeluarga merupakan satu gejala sosial yang bersifat universal, artinya dalam semua masyarakat akan ditemukan gejala ini. Setiap orang akan masuk dalam satu kelurga tertentu dan yang merupakan bagian dari satu masyarakat yang lebih besar. Dengan demikian setiap orang mempunyai status tertentu dalam keluarga, baik dalam arti yang sempit maupun dalam arti yang luas. (Ritonga:1996). Satu keluarga, dimanapun merupakan satu sistem pengelompokan dan merupakan pranata sosial yang universal.Sifat yang universal itu disebabkan oleh adanya fungsi yang dapat memenuhi kebutuhan-kebutuhan dasar manusia, sejak manusia itu lahir sampai menjadi dewasa dan tua.Keluarga yang mempunyai landasan emosional yang kuat merupakan keluarga yang tahan uji dan teruji oleh zaman. (Ritonga:1996)

Menurut Hasono dalamRitonga (1996) bahwa keluarga ini adalah kelompok yang batas-batasnya ditetapkan oleh hubungan seks yang teratur, secara tepat dan tahan lama serta untuk mendapat dan mengasuh keturunan. Dengan kata lain dapat dikatakan bahwa keluarga ini adalah kelompok manusia yang terkait oleh ikatan-ikatan perkawinan, ikatan 
darah atau adopsi yang membentuk sebuah rumah tangga yang saling bertindak dan berhubungan dalam masing-masing peranannya sebagai ayah, ibu dan anak-anaknya yang membentuk dan memelihara kebudayaan.

Keluarga merupakan kelompok primer yang paling penting di dalam masyarakat.Keluarga merupakan sebuah group yang terbentuk dari perhubungan laki-laki dan perempuan, perhubungan yang berlangsung lama untuk menciptakan dan membesarkan anak-anak.Jadi, keluarga dalam bentuk yang murni merupakan satu kesatuan social yang terdiri dari suami, istri dan anak-anak yang belum dewasa atau belum menikah.Ketiadaan anak-anak tidaklah menggugurkan status keluarga, maksudnya faktor anak bukanlah faktor mutlak untuk mewujudkan suatu keluarga.Suatu keluarga yang kebetulan tidak dikaruniai anak, tetap mempunyai status keluarga. Dengan kata lain, keluarga seperti itu tetap berhak dianggap sebagai keluarga. (Ritonga:1996). Perubahan fungsi dalam keluarga dapat dipengaruhi oleh status sosial ekonomi, tekhnologi, adat istiadat dan jumlah keluarga. Hal-hal yang mempengaruhi perubahan fungsi ibu rumah tangga dalam kluarga itu akan dijelaskan secara sekilas dibawah ini :

1) Status Sosial

Menghadapi perubahan-perubahan yang terjadi, khususnya dalam struktur keluarga, mengakibatkan pola perubahan fungsi keluarga.Pembagian kerja dan diferensiasi peran dalam keluarga, maka aspek nilai-nilai yang dianut perlu diperhatikan agar tidak salah arah.Anggota keluarga yang berada diluar rumah (peran instrumental).Perubahan fungsi ekonomi keluarga mempengaruhi pembagian tugas anggota-anggotanya.Fungsi mengawasi perbaikan rumah, membayar listrik dan sebagainya, yang semula menjadi tugas suami sekarang diambil alih oleh istri.Sebaliknya suami mulai membantu membersihkan rumah, memasak, mengurus anak dan sebagainya.Dengan demikian terjadi pergeseran peran instrumental ekspresif menurut jenis kelamin. (Rustina:2000).

\section{2) Tekhnologi}

Masuknya tekhnologi yang mempengaruhi peranan wanita dalam rumah tangga memberikan peluang bagi wanita lebih banyak berperan diluar rumah tangga.Mencuci dengan tenaga manusia digantikan digantikan dengan mesin cuci, memasak dengan kayu atau kompor digantikan dengan rice cooker, yang mencirikan zaman torabolisasi, menjadikan ibu rumah tangga lebih banyak waktunya. Perubahan-perubahan yang diakibatkan oleh tekhnologi bagi keluarga di pedesaan berdampak terhadap kegiatan 
ekonomi para wanita, terutama dalam kalangan keluarga miskin, yakni para wanita yang tidak mengalami dari perubahan-perubahan tekhnologi terhadap kehidupan mereka didesa-desa utamanya para wanita. (Rustina: 2000)

3) Adat Istiadat

Setiap negara atau daerah memiliki pandangan berbeda-beda mengenai peran perempuan.Pada budaya amerika, wanita ditetapkan secara seksual dan sosial berkenaan dengan daya tarik fisik mereka.Sifat wanita adalah lemah sehingga tidak layak memerankan peran yang berkenaan dengan kecerdasan, kesuksesan dan sumber-sumber finansial. (Russel dalam Hijriani: 2011). Pembagian kerja tradisional dalam keluarga miskin biasanya dianggap "alami”. Pengertian ini menjelaskan bahwa sejak awal ditimbulkan oleh perbedaan jenis kelamin itu sendiri, akan tetapi para anggota suatu masyarakat tertentu memandang pembagian kerja menurut jenis kelamin sebagai alami kerena selama generasi sedikit atau tidak mengalami perubahan, masyarakat yang lainnya mempunyai cara atau pola yang berbeda dalam pembagian kerja mereka sama alaminya (Hijriani: 2011)

4) Besarnya anggota keluarga

Pria (suami) adalah tumpuan harapan untuk memenuhi kebutuhan ekonomi keluarga dalam rangka peningkatan kualitas penduduk.Sementara jumlah anggota keluarga yang banyak (large size family) menyebabkan pria (suami) kewalahan untuk memenuhi semua kebutuhan hidup semua anggota keluarga, sehingga memerlukan bantuan anggota lainnya untuk membantu mencari nafkah.Besar tantangan yang dihadapi dalam keluarga, menjadi pendorong bagi istri untuk membantu suami mencari nafkah agar kebutuhan keluarga dapat terpenuhi.

\section{METODE PENELITIAN}

Penelitian ini merupakan penelitian kualitatif yang bersifat deskriptif, umtuk memahami fenomena tentang apa yang dialami oleh Masyarakat Bungung Katammung Kabupaten Bantaeng. Teknik penarikan sampel yang digunakan dalam penelitian ini adalah secara purposive sampling atau teknik pengambilan sampel secara sengaja dengan berdasarkan karakteristik tertentu bahwa responden tersebut memiliki kapabilitas serta kredibilitas yang sesuai dengan permasalahan dalam penelitian ini, dimana mereka bisa memberikan informasiinformasi yang sangat akurat sesuai dengan apa yang mereka alami dalam kehidupan sehari-hari.Teknik yang digunakan untuk memperoleh data yang dibutuhkan dalam penelitian ini adalah metode observasi, wawancara, dan 
dokumentasi.Analisi ini dilakukan dengan cara menyusun, mereduksi data, mendisplay data yang dikumpulkan dari berbagai pihak dan memberikan verifikasi untuk disimpulkan.Sedangkan teknik keabsahan data melalui triangulasi sumber, triangulasi teknik dan triangulasi waktu.

\section{PEMBAHASAN}

1) Peran Ganda Istri Komunitas Petani Padi di Masyarakat Bungung Katammung Kabupaten Bantaeng sangatlah besar dalam suatu keluarga termasuk didalam untuk mencari nafkah demi membantu peningkatan ekonomi keluarga.

a) Lingkup Domestik yaitu mengeaar, mendidik anak, memasak makanan untuk suami dan anak-anak, mencuci piring, gelas atau peralatan lain yang digunakan untuk keperluan makan, mencuci pakaian suami dan anak-anak dan membersihkan rumah seperti menyapu dan mengepel lantai rumah.

b) Lingkup publik yaitu (1) Membantu pekerjaan suami di sawah mulai dari menanam padi, memupuk padi, membersihkan tanaman padi dari rumput, mengaliri air, menjaga padi dari binatang penganggu seperti burung, memotong sampai membawa hasil panen padi dari sawah ke rumah dengan cara menjinjing (nyongong).Sampai di rumah pekerjaan para Komunitas petani dilanjutkan dengan menjemur padi sampai kering, sehingga siap untuk di pabrik, kegiatan untuk mengelolah padi menjadi beraspun dilakukan oleh para istri. (2) Membantu pekerjaan suami di kebun mulai menanam jagung di kebun atau tananan yang lain seperti, kacang, ubi atau sayur-sayuran, memupuk tanaman, membersihkan tanaman dari rumput penganggu, memetik jagung sampai ada juga para istri yang membantu membawa hasil paneng jagung ke rumah meskipun hanya sedikit. (3) membantu suami dalam mencari makanan ternak sampai mengembalakan ternak di sawah atau di kebun.

2) Dampak Peran Ganda Istri Komunitas Petani yang bekerja pada ruang lingkup domestik dan publik memiliki berbagai implikasi positif dan negatif.

a) Dampak Negatif

1) Perasaan bersalah yaitu perasaan merasa bersalah karena tidak dapat menjalankan perannya sebagai ibu dengan baik 
2) Stres yaitu ingin mencurahkan segala waktu dan perhatiannya untuk anak-anak, namun keinginan itu berbenturan dengan realitas terus bekerja untuk membantu suami dalam menopang kehidupan keluarga.

3) Kelelahan yaitu melakukan aktifitas pekerjaan yang setiap hari banting tulang membantu suami mencari nafkah untuk kebutuhan keluarga.

4) Ketidakberdayaan yaitu tidak bisa mengawasi semua aktifitas anaksecara di rumah karena bekerja diluar rumah.

5) Kecemasan yaitu Perasaan seorang ibu tidak tenang atau takut terjadi apa-apa pada saat hendak berangkat kerja dan harus menitipkan anak-anak pada neneknya atau keluarganya.

6) Kesedihan yaitu harus membagi waktu antara anak-anak dan pekerjaannya diluar rumah dan melihat anak-anaknya nakal

7) Kemarahan : masih banyaknya pekerjaan yang belum selesai dikerjakan pada saat pulang ke rumah.

b) Dampak Positif

Beberapa dampak positif yang dialami setiap istri dalam menjalankan perannya :

1) Peningkatan perilaku beragama

Semua beban yang dirasakan oleh setiap istri dalam menjalankan peran ganda membuatnya semakin dekat pada Allah Swt. Hal tersebut dilakukan sebagai bentuk pengabdian kepada suami dan untuk menghidupi kebutuhan anak-anak..

2) Mendukung ekonomi keluarga

Bekerja membuat seorang istri dapat membantu suami memenuhi kebutuhan keluarga dan anak-anak dengan memperoleh penghasilan yang dapat digunakan untuk membantu suami mencukupi kebutuhan hidup keluarga.

3) Relasi positif dalam keluarga

Keluarga bisa saling bekerja sama satu dengan yang lainnya. Istri bekerja membantu suami mancari nafkah sehingga suaminya sangat mendukung karena merasa tidak bisa mencukupi kebutuhan keluarga dengan hasil kerjanya sendiri.Suami juga bersedia mengerjakan tugas-tugas domestik tanpa mengeluh bila merasa istrinya sedang kelelahan. Anak-anak mereka juga sangat membantu dalam menyelesaikan tugas-tugas domestik sepulang dari sekolahnya.

4) Pemenuhan hubungan sosial 
Istri yang bekerja merasa senang karena memiliki teman yang bisa ia temani berangkat dan pulang bersama-sama dari sawah atau pulang dari kebun bekerja membantu suami masing-masing.

\section{KESIMPULAN}

1. Perang ganda istri komunitas petani dalam lingkup domestik yaitu : Memasak, dan membersihkan rumah dan memdidik anak sedangkan dalam lingkup publik membantu pekerjaan suami di sawah dikebun dan membantu memelihara ternak.

2. Dampak negatif yaitu perasaan bersalah, stres, kelelahan, ketidakberdayaan, kecemasan, kesedihan dan kemarahan, sedangkan dampak positifnya yaitu meningkatkan perilaku beragama, mendukung ekonomi keluarga, relasi yang sehat dan positif dengan keluarga dan pemenuhan hubungan sosial.

\section{DAFTAR PUSTAKA}

Arikunto.(1998). Prosedur Penelitian (Suatu Pendekatan Praktek).Jakarta: PT. Reneka Cipta.

Goode, William J. (2007). Sosiologi Keluarga. Jakarta: PT. Bumi Aksara.

Hariwijaya \& Triton.(2007). Pedoman Proposal dan Skripsi.Yogyakarta: Oriza.

Koentjaraningrat. 1965. Pengantar Antropologi. Jakarta : Penerbit Universitas.

R.M MacIver \& Charles H. (1961) .Society, an Introductory Analysis.London : Macmillan \& Co.

Soekanto, Soerjono. (2012). Sosiologi Suatu Pengantar.Jakarta : PT RajaGrafindo Persada.

Soemardjan dan Soelaeman Sumardi.(1964). Setangkai Bunga Sosiologi.Jakarta: Yayasan Badan Penerbit Fakultas Ekonomi Universitas Indonesia.

Sugiyoni.(2012). Metode Penelitian Kuantitaf, Kualitatif dan R\&D. Bandung: Alfabeta.

Tylor, E.B. (1924). Primitive Culture. New York: Brentano's.

Tukidjan, Eddy, Dkk. (2009). Sosiologi Pendidikan. Makassar: Departemen Pendidikan Nasional.

Walgito, Bimo. (2003). Psikologi Sosial (Suatu Pengantar). Yogyakarta: Penerbit Andi.

Ollenburger, Jane. (1996). Sosiologi Wanita.Jakarta : PT. Rineke Cipta. 
Arfah, Muhammad, Dkk. (1997). Fungsi Keluarga Dalam Meningkatkan Kualitas Sumber Daya Manusia Daerah Sulawasi Selatan. Ujung Pandang: CM. Maju Jaya Ujung Pandang.

Hijriani, Jum. (2011). Peran Ganda Ibu Rumah Tangga Dalam Meningkatkan Pendapatan Keluarga (Studi Kasus Pemecah Batu di Desa Lamatti Rilau Kecamatan Sinjai Utara). Makassar: Skripsi Fakultas Ilmu Sosial UNM.

Ritonga.(1996). Fungsi Keluarga dalam Meningkatkan Kualitas Sumber Daya Manusia Daerah Sumatera.Medan: Departemen Pendidikan dan Kebudayaan Republik Indonesia.

Rustina.(2000). Peranan Istri Petani dalam Keluarga dan Masyarakat di Kecamatan Burau Kabupaten Luwu. Makassar: Tesis Program Pasca Sarjana UNM.

Said, Ridwan.(2001). Pola Pencaharian Nafkah Perempuan Pedesaan (Kasus di Desa Sumberejo Kec. Wonomulyo Kab. Polmas).Makassar: Tesis Program Pasca Sarjana UNM.

Sjafnir.(1988). Kedudukan dan Peranan Wanita dalam Kebudayaan Suku Bangsa Minangkabau.Jakarta: Departemen Pendidikan dan Kebudayaan.

Wahidah, Nurul. (2008). Peranan Perempuan dalam Perekonomian Keluarga (Kasus Tukang Cuci dari Kelurahan Tombolog Kab.Gowa).Makassar: Skripsi Fakultas Ilmu Sosial UNM.

Borut, Fitriani, (2012). Makalah Antropologi Masyarakat Peasent. (http:// blogspot.com/2012/02/makalah-antropologi-masyarakat-peasent/, diakses 18 Juni 2014).

Ferawati.(2013). Pengertian Masyarakat.(http://ferawati1.blogspot.Com/2013/02 /pengertian-masyarakat-menurut-beberapa-ahli.html,diakses 18 Juni 2014)

Rahmawati, Annisaa, (2012). Komunitas Sosiologi Pertanian. (http://blog.ub.ac.id/ annisaarahmawati/2012/04/komunitas-sosiologi-pertanian/, diakses 18 Juni 2014). 